\title{
REPATRIATION OF PRISONERS OF WAR AND THE 1949 GENEVA CONVENTION
}

\author{
JAN P. CHARMATZ广 and HAROLO H. HITTi
}

REPATRIATION of prisoners of war has created an impasse in world politics and a challenge to international law. Failure to agree on a policy for the release of prisoners captured in Forea is claimed to be the only remaining reason for continued loss of life in combat and the prolonged detention of hundreds of thousands of soldiers in prison compounds. ${ }^{1}$ Thus hopes for peace in Asia and for reduction in world tension devolve in large part on the outcome of a debate-concerning a single point in international lawwhich has dragged on for over a year in the Panmunjom truce talks and which will continue to concern the United Nations General Assembly in its present session. From the outset the communists have demanded the repatriation of each and every prisoner captured by United Nations forces in Korea. ${ }^{2}$ The United Nations has vigorously opposed this position. Originally, the United Nations Command claimed that the principle of "voluntary repatriation" should govern the exchange of prisoners and that only those who "elect[ed] repatriation" should be sent home. ${ }^{3}$ Later, U.N. negotiators withdrew this formula and substituted for it the principle of "no forced repatriation," which forms the core of the present controversy:

"[A]11 prisoners of war must be relcased but only those should be repatriated or turned over to the other side who can be delivered without the application of force."'s

$\leftarrow$ Visiting Lecturer in Law, Yale Law School.

iٓLieutenant (j.g.), U.S.N.R.

The opinions and assertions contained in this article are the private ones of the authors and are not to be construed as official or reflecting the views of the Navy Department or the Naval Service.

1. See. e.g., Korea: A Sumarary of Developarents in the Arumstice Nirotrations and the Prisoner of WAr Casips, June 1951-Miny 1952, Card. No. 8595 at 11, 21-6 (1952) ; 45th Report of the United Nations Command Operations in Korca, 27 Der'T STATE BULL 272-3 (1952).

2. See Korea: A SuMmary, op. cit. supra note 1, at 20-1.

3. Id. at 9, 18. In January, 1952, during the armistice negotiations in Korea, the Cnited Nations Command introduced a proposal "designed to insure that prisoners vere only repatriated with their own consent, i.e., prisoners would have the right to choose to be set free on either side of the armistice demarcation line. ... This [proposal] was rejected by the Communists. The United Nations Command later receded frum thi prin. ciple of 'voluntary repatriation' to that of 'no forced repatriation.' "Id. at 8 .

For an account of the early phases of the Korean truce talls with reference to the repatriation issue, see (Admiral) Joy, My Batile Inside the Korca Truee Tent. Collier's, Aug. 16, 1952, p. 36; Aug. 23, 1952, p. 26; Aug. 30, 1952, p. 70.

4. Korea: A SuMMrary, op. cit. suspra note 1, at 20-1. 
This position has been maintained by the United Nations since April, 1952. Past treatment given repatriated nationals of communist countries convinced the leaders of the Western powers that Chinese and North Korean prisoners on their return would be exposed to deprivations of human rights. ${ }^{5}$ Although U.N. leaders stated they would not retain prisoners who wished to return home, ${ }^{6}$ they felt that repatriation by force would be inconsistent with the humanitarian principles of the Geneva Convention. To ascertain if force would be required to send prisoners home, the United Nations in April, 1952, screened captured Chinese and North Koreans. Interrogation showed that out of 170,000 captives only 70,000 , or 40 percent, wotuld not forcibly resist repatriation. ${ }^{7}$ Openly expressed anti-communist feelings of many prisoners and the actual segregation of these captives after interrogation made it probable that home states would learn of their opposition to repatriation. The United Nations felt that this knowledge in the hands of communist governments increased the likelihood that many thousands of war captives would be subjected to severe deprivations. Recognizing the gravity of the situation, President Truman declared: "We must not use bayonets to force these prisoners to return to slavery and almost certain death at the hands of the communists." To use force, British Foreign Secretary Eden maintained, "would . . . be repugnant to the sense of values of the free world."

5. See Hurndall, Crimea Disagreenent, 44 The ArMy QUARTERLY 84, 94 (1952); see also Department of State, Forced Labor in the Soviet Union 11 (1952).

"The very fact of his captivity was the accusation leveled against every Soviet prisoner of war." Dallin \& NTCOLAEvSKY, ForCed LABOR IN SOVIET Russin 296 (1947).

"In 1941 came the first convoys of Finns and detachments of Red Army soldiers who had been captured on the Finnish front; these soldiers had marched under a decorated triumphal arch in Leningrad, welcomed by streamers with the legend 'The Fatherland greets its heroes,' and to the strains of the Budyenny March had been led straight to a railroad siding beyond the town where sealed cattle trucks were waiting to take them to the [labor] camps." Herding, A Worrd ApArt 65-6 (Mentor ed. 1952).

6. This very position was adopted by the General Assembly in its Resolution, 427 (V) of December 14, 1950, which dealt with the detained World War II captives who "should ... have been repatriated long since." The Resolution further stated: "[A]11 prisoners should ... be given unrestricted opportunity of repatriation." YEAREOOK or THE UNITED NATTONS-1950, p. 568 (1951).

7. Between the 5th and 15th of April, 1952, most Chinese and North Korean captives were interrogated by the United Nations Command. KoREa: A Sumurar, op. cil. supra note 1 , at 10 . On April 19, 1952, the communist armistice delegation was informed that of the 170,000 held by the United Nations, only approximately 70,000 would not resist repatriation. For a breakdown of these figures according to North Korean soldiers, Chinese soldiers, etc., see KeEsing's Contemporary Arcurves 12194 (1952). By July the final figures of the screening were made available to the communists. They showed " 83,000 prisoners who would not oppose repatriation including approximately 6,400 Chinese prisoners." 50th Report of the Unitcd Nations Command Operations in Kored, 27 Dep't State Bull. 958 (1952). For the text of the questions put to the prisoners, see note 103 infra.

8. N.Y. Times, Aug. 21, 1952, p. 1, col. 4.

9. Korea: A SumMary, op. cit. supra note 1, at 24. 
All parties to the dispute have treated the issue of repatriation as a matter of international law alone. A member of the Indian delegation to the United Nations has declared: "The Chinese themselves and the Koreans themselves have demanded that repatriation shall take place in terms of international law. So far as we are concerned, therefore, this is common ground." 10 The General Assembly has agreed. ${ }^{11}$ Its Resolution of December 3, 1952, stated:

" $[\mathrm{T}]$ he release and repatriation of prisoners of war shall be effected in accordance with the "Geneva Convention Relative to the Treatment of Prisoners of WVar,' dated 12 August 1949, the vell-established principles and practices of international law and the relevant provisions of the draft armistice agreement."12

For the purposes of this discussion it is not important whether this apparent respect for international law is genuine or motivated by a conviction that effective ideological warfare requires such an approach to the repatriation issue. What is important is that the U.S.S.R., China, and North Korea have insisted that international law supports their stand, and have attacked the United Nations position as a flagrant violation of the 1949 Geneva Convention. ${ }^{13}$

Although discussed exclusively as a problem of legal doctrine, the disposition of Korean prisoners of war will, of course, be determined by political considerations growing out of the larger world-wide power struggle between the communist and non-communist worlds. Yet one source of strength in the Korean controversy-and in the global conflict as well-lies in the ability of each of the major national governments to gain support for their policies from other nations and from their own citizens as well. Support for policies hinges on peoples' identifications; these, in turn, are shaped in part by conceptions of what is right and wrong. ${ }^{14}$ And the "right" and "wrong" of the Korean repatriation issue may well be linked by millions with the proper application of the 1949 Geneva Convention. Competing interpretatiuns of the Convention are thus important political weapons in the dispute over th:

10. Statement of the Representative of India, MIr. Menon, at the 525th Mecting 6f Committee I, Nov. 19, 1952. U.S. DELEG. Doc. US/A/C.1/2542, p. 7 (1952).

11. "The [General Assembly's] First Committee's general debate on the Korear question was concluded on November 24, exactly a month after it began. Fiity-thrce statements had been made at seventeen meetings. There were five draft resolutions-a joint 21-nation proposal, and those of the U.S.S.R., Mexico, Peru, and India." The Scarch for an Agreed Solution on Repatriating Korca Prisoners, 13 U.N. BuLL 487 (1952). On the basis of these discussions Committee I passed a resolution which was adopted by the General Assembly on December 3, 1952.

12. N.Y. Times, Dec. 2, 1952, p. 3, col. 1; Dec. 4, 1952, p. 3, col. 1.

13. See, e.g., Statements of the Representative of the U.S.S.R., Mr. Vyshinsly, at the 514th Meeting of Committee I, Oct. 29, 1952, U.S. Des.be. Doc. US/A/C.1/2538, p. 86 (1952); and at the 529th Mleeting of Committee I, Nov. 24, 1952, U.S. Deles. Dee. US/A/C.1/2543, pp. 2, 5 (1952).

14. See MrcDougal, Law and Power, 46 Ass. J. Ist'L L. 102 (1952). 
Korean prisoners of war. Moreover, if the controversy's solution, however politically motivated, is consistent with a reasonable construction of international law, this consistency will help to further the United Nations' goal of a world order based on law.

No doctrinal analysis of specific Convention articles, however, has been advanced during the Korean debates by any statesman except one-the delegate from the Soviet Union, Mr. Andrei Vyshinsky. And because all nations concerned talk about the issue at least in general legal terms, because conceptions of right and wrong are significant sources of power, and because of the importance of establishing a world order based on law, a doctrinal analysis of the 1949 Geneva Convention is necessary. Such an inquiry must determine both the correct interpretation of pertinent treaty provisions and their application to specific factual situations, particularly the present Korean impasse.

\section{Interpreting the 1949 Geneva Convention}

The attack on the United Nations position and the alternative offered to it are based on an attempted "literal" reading of Articles 118 and 7 of the 1949 Geneva Convention Relative to the Treatment of Prisoners of War. ${ }^{10}$ The first paragraph of Article 118 reads:

"Prisoners of war shall be released and repatriated without delay after the cessation of active hostilities."10

15. Though the 1949 Convention has not been ratified by the signatories, nevertheless, it has been accepted as governing by the United Nations. Kores: A SUMMARY, op . cit. supra note 1, at 26. Not only has the United Nations recognized the Convention. On July 13, 1950, the North Korean authorities declared that they would abide by the 1949 Convention on prisoners of war ; and on July 16,1952 , the Chinese communists, with reservations, made a similar pledge. N.Y. Times, July 25,1952 , p. 1 , col. 3.

Recognition of the 1949 Convention by all parties concerned in Korea is in accord with the general view that the rules concerning land warfare and the treatment of captives are applicable with or without formal adhesion to a treaty, since they themselves are only codifications of generally recognized customs of war. 2 OPPEN HENM, INTERNATIONAL LAW 234 (7th ed., Lauterpacht, 1952).

16. Geneva Convention Relative to the Treatalent of Prisoners of Wak of August 12, 1949, Art. 118 (1949), provides in full :

"Prisoners of war shall be released and repatriated without delay after the cessation of active hostilities.

"In the absence of stipulations to the above effect in any agreement concluded between the Parties to the conflict with a view to the cessation of hostilities, or failing any such agreement, each of the Detaining Powers shall itself establish and execute without delay a plan of repatriation in conformity with the principle laid down in the forcgoing paragraph.

"In either case, the measures adopted shall be brought to the knowledge of the prisoners of war.

"The costs of repatriation of prisoners of war shail in all cases be equitably apportioned 
Article 7 states:

"Prisoners of war may in no circumstances renounce in part or in entirety the rights secured to them by the present Convention, and by ... special agreements. . ..."17

Mr. Vyshinsky, the most vociferous "literalist," maintains there is no need to look behind the words of Article 118; captor states are obligated to repatriate all prisoners of war without exception, no matter what the prevailing conditions-and that is all there is to it. After considering "the categoric formula" of Article 118, he queries:

"Is that not clear? No agreement is necessary; . . nothing at all is necessary. The International Convention of 1949 is self-enforcing, because it says: in the absence of agreement, each of the powers which holds war prisoners shall, must, is compelled by itself, on its own account, to draw up and carry out a repatriation plan in keeping with the principles set out above [Articles 118 and 7].... Now, what are you going to do about that? Here is a principle of international law."18

And Mr. Vyshinsky contends that the principle of Article 118 sets forth a right made irrevocable by Article 7. "In other words, there is a special article which says that war prisoners are not entitled to waive their rights. . . . What right? The right to be repatriated."10 To MIr. Vyshinsky the "literalist" view is the only one, the reflection of the "categoric formula," the "principle of international law." To him the words of the Convention are compelling.

between the Detaining Power and the Power on which the prisoners depend. This apportionment shall be carried out on the following basis:

"(a) If the two Powers are contiguous, the Power on which the prisuners of war depend shall bear the costs of repatriation from the frontiers of the Detaining Power.

"(b) If the two Powers are not contiguous, the Detaining Pover slall hear the costs of transport of prisoners of war over its own territory as far as its froutiu $\mathrm{ur}$ it i f rt of embarkation nearest to the territory of the Power on which the pristners of war 4 . pend. The Parties concerned shall agree hetween themselves as to the expitahle aldit artionment of the remaining costs of the repatriation. The conclusion of this asteement itall in no circumstances justify any delay in the repatriation of the prisuners of var."

The four 1949 Geneva Conventions are printed in Sex. E:iEc Doc Letress D, E, I, \& G, s2d Cong., 1st Sess. (1951). The four, along with previous conventions cuncerving the rules of war, also are reprinted in 47 NAval WaR College, Inti LAy Docungeits (1952).

17. Art 7 of the 1949 Convention in full provides:

"Prisoners of war may in no circumstances renounce in part or in entirety the rights secured to them by the present Convention, and by the special agreements referred to in the foregoing Article, if such there be."

18. Statement of Mrr. Vyshinsky to the 514th Mecting of the Political and Security Committee (Committee I of the General Assembly) of the United Nations, Oct. 29, 1952. U.S. DEIEG. Doc U.S./A/C.1/2538, pp. S6-7 (1952).

19. Id. at $S S$.

20. Id. at 86,87 . 
They embody "the law." And a "law cannot be turned around like a cart in various directions and pulled hither and yon; it cannot be used as a shuttlecock." 21

Literalist thinking about statutes and treaties assumes that words are 111 ambiguous and therefore require no interpretation. ${ }^{22}$ But to apply statutes and treaties to specific situations, decision-makers must always interpret, since words gain meaning only from context. ${ }^{23}$ What are statutes and treaties without interpretation? "Nothing but a combination of paper and printer's ink."24 Thus Mr. Vyshinsky cannot claim his position is the truth. It represents his interpretation of the 1949 Convention. In effect, Mr. Vyshinsky reaches his position on repatriation by adding words to Articles 118 and 7. Article 118 seems to emerge as:

Detaining powers are required to release and repatriate all prisoners of war without delay after the cessation of hostilities no matter what prisoners wish, and no matter what deprivations may await them when they return home.

And Article 7 becomes:

Prisoners of war may in no circumstances renounce in part or in entirety the rights secured to them by the Convention and by special agreements even if the enforcement of a right would be a deprivation for them.

The real issue is not whether or not the literalist view is "the law" and the United Nations position "an interpretation"; the issue is which interpretation is compatible with generally accepted modern principles of treaty interpretation. When decision makers interpret a treaty, they give its text meaning for a specific problem. ${ }^{25}$ But statesmen cannot legitimately give treaty

21. Id. at 94 .

22. Id. at 86. An attempt to show that the words of Art. 27 of the U.N. Charter are unambiguous and mandatory and that there is "scarcely any room for doubt" was made by Professor Gross. Gross, Voting in the Security Council: Abstention from Voting and Absence from Meetings, 60 YALE L.J. 209 (1951). He attempted to prove that the voting procedure of the Security Council on the Korean Resolution of June, 1950, was "illegal." The defects and dangers of this mode of thinking were shown by $\mathrm{McD}$ ougal \& Gardner, The Veto and the Charter: An Interpretation for Strvival, 60 YALE L.J. 258, 262-9 (1951).

23. See, e.g., Chase, The Tyranny of Words (1938).

24. Schlossmann, Der Irrtun ueber wesentliche Eigenschaften der Penson und der Sache nach deat Buergerlichen Gesetzbuch: Zugi.eicu ein Beitrag zur Theorie der Gesetzesauslegung 27 (1903) (authors' translation). See also MeDougal \& Gardner, supra note 22, at 263.

25. "Few terms of art may be said to exist in international law, and as the terms employed in international instruments seldom have an exact meaning, they can be interpreted only by giving content to them. This is not a matter of mechanical operation; it is not a process which performs itself automatically; results have to be kept in mind, judgment must be exercised, many factors must be appreciated." Hudson, Tuz Pesus NENT Court of INternational Justice 1920-1942, pp. 641-2 (1943). See also, Harvard Research Draft on Treaties, 29 AM. J. INT'L L. Supp. 653, 946 (1935). 
words any meaning or referents they wish. They are limited among other things by the signatories' major demands and expectations, ${ }^{26}$ evidenced by' treaty purposes and legislative history. By making their purposes clear, the framers of the 1949 Geneva Convention erected certain barriers designed to limit the meaning future officials could give to Convention words. ${ }^{27}$ The legislative history of Articles 118 and 7 impose additional limitations. ${ }^{28}$. Int interpreters must also consult the doctrines and practices of international law which constituted the drafters' frame of reference and, as such, form an integral part of legislative history. ${ }^{29}$ Yet since treaty maliers cannot foresee the future, officials must adapt interpretations to conditions existing at the time of decision. The Harzard Research Draft on Treatics agrees with this formulation of principles of treaty interpretation:

"A treaty is to be interpreted in the light of the general purpose which it is intended to serve. This historical background of the treaty, travaux préparatoires, the circumstances of the parties at the time the treaty was entered into, the change in these circumstances sought to be effected, the subsequent conduct of the parties in applying the provisions of the treaty, and the conditions prevailing at the time interpretation is being made, are to be considered in connection with the general purpose which the treaty is intended to serve."

\section{Convention Purposes}

Few treaties exist whose major purposes are as obvious as those of the 1949 Geneva Convention Relative to the Treatment of Prisoners of VVar. Delegates to the 1949 Geneva Diplomatic Conference characterized their work as "inspired solely by humanitarian aims."31 The Convention itself is designed for the "protection" of prisoners of war.32 The text provides that prisoners of war must be protected against violence or intimidation and humanely treated "at all times." 33 They are to be spared insults to their dignity as human beings. ${ }^{34}$ And captors are warned that "any unlawifl act

26. MicDougal \& Gardner, sipra note 22 , at 266 n.37.

27. For a full discussion of the purposes of 1949 Geneti Conientro: RElative to the Treamient of Prisoners of War, see test at pages $397-8$ infro.

23. For a discussion of the legislative history of the Cunvention, sse test at pages $398-105$ infra.

29. For a discussion of doctrines and practices of international law relevant tu repatriation of prisoners of war, see text at pages $405-9$ infru.

30. Harziard Research, sipra note 25, at 937.

31. Resolutions of the Diplomatic Conference of Geneva, 1949, Res. \&, SE::. Exrs. Doc. Letrers D, E, F, \& G, 82d Cong., 1st Sess. 22 (1951).

32. The full title of the Convention reads: Geneva Cosvestron Renarrve to rHe Treatarevt of Prisoners of War, August 12, 1949 (1949). It is one of four Ge.reva Contentions for the Protection of WAR Victrass (1949), all of which were opened for signature on the same day.

33. Geneta Convention Relative to the Treatarent of Priso:iers we Wais, August 12, 1949, Art. 13 (1949).

34. Id. at Art. 14. 
or omission by the Detaining Power causing death or seriously endangering the health of a prisoner of war in its custody is prohibited, and will be regarded as a serious breach of the present Convention."35 Provisions governing repatriation, like all other parts of the Convention, must be viewed in the light of these purposes. ${ }^{36}$

By recalling the climate of opinion existing after World War II, one can appreciate the Drafters' deep commitment to humanitarian principles. The Convention was written during a period of increasing awareness that the protection and promotion of human rights are intimately associated with the conditions necessary to secure permanent peace. The Charter of the United Nations, the Universal Declaration of Human Rights, the Draft Covenants of Human Rights, the Genocide Convention, as well as the 1946 General Assemby Resolution on Refugees, all indicate that awareness. The so-called "literalist" interpretation fails to consider as significant this concern which is expressed in the purposes of the Convention and in its legislative history as well.

\section{Legislative History: Convention Conferences}

The genesis of the Convention as recorded shows that the words of Article 118 represent an attempt to improve upon Article 75 of the 1929 Convention Relative to the Treatment of Prisoners of War in the light of the experience of World War II. ${ }^{37}$ Article 75 of the 1929 Convention provided that in the event of an armistice, belligerents "in principle" were obligated to "have appear therein stipulations regarding the repatriation of prisoners of war." If belligerents made no such stipulations, then they were to conclude a repatriation agreement "as soon as possible." "In any case," however, repatriation was to be effected "with the least possible delay after the conclusion of peace." Un8 Under a literal interpretation of the 1929 Convention, detaining

35. Id. at Art. 13.

36. In addition to its purposes a decision-maker when interpreting should also consider the legislative history of the treaty, general principles of international law and the conditions prevailing at the time the interpretation is being made. See McDougal \& Gardner, supra note 22, at 266 et seq.; and see also text at pages $396-7$ supra.

37. Geneva Convention Relattve to the Treatnient of Prusoners of War, 27 JuLx 1929, Art. 75 (1929). For a comparison between the 1929 and 1949 Conventions, see Gutteridge, The Geneva Conventions of 1949, 26 BruT. Y.B. INT'1 L. 294 (1949). An appraisal of the 1949 Conventions is made in Yingling \& Ginnane, The Gencva Corm ventions of 1949, 46 Axr. J. INT'L L. 393 (1952). For a brief general discussion on repatriation, see Potter, Repatriation of Prisoners of War, 46 AM. J. INr'L L. 508 (1952). The most thorough discussion of past repatriation practices is GoTTLIED, REPATRuATION in Theory and in Practice Througrout the First World War (unptublished thesis in Bryn Mawr College Library, 1945).

38. Geneva Convention Retative to the Treatment of Prisoners of War, 27 JuLy 1929, Art. 75 (1929) reads in full:

"When belligerents conclude a convention of armistice, they must, in principle, have appear therein stipulations regarding the repatriation of prisoners of war. If it has not 
powers, on the pretext of complying with the letter of Article 75, could rationalize their retention of prisoners until peace treaties were signed. ${ }^{39}$. And World War II experience showed that final settlements between belligerentspeace treaties or unilateral declarations-often are delayed for many years after hostilities end or perhaps indefinitely. 10 To prevent the detention of prisoners long after any apparent military reason for their captivity remained was a major reason for the "categorical" language of Article 118 of the 1949 Convention. ${ }^{41}$ Article 118 attempted to improve on Article 75 of the 1929 Convention, by introducing a definite time- "after the cessation of hostilities" -when detaining powers are obligated to repatriate prisoners of war. IV'hat was not changed was the nature of the obligation itself.

At the Conference of Government Experts, which met at Geneva in 1947 to consider International Red Cross proposals for a new convention, IVorld

been possible to insert stipulations in this regard in such convention, belligerents shall nevertheless come to an agreement in this regard as soon as possible. In any case, repatriation of prisoners shall be effected with the least possible delay after the conclusion of peace.

"Prisoners of war against whom a penal prosecution might be pending for a crime or an offense of municipal law may, however, be detained until the end of the procerdings and, if necessary, until the expiration of the punishment. The same shall be true of those sentenced for a crime or offense of municipal law.

"On agreement between the belligerents, commissions may be established for the purpose of searching for dispersed prisoners and assuring their repatriation."

This article represented an improvement over Art. 20 of the HAGCE Cosive:rro: (IV) Respecting THe Laws and Custorss of WAR on LAsjd (1907) and Art. 20 of the Hague Contention (II) with Respect to the Laws and Custons of War on Lazid (1899), which both contained merely the following provision:

"After the conclusion of peace, the repatriation of prisoners of war shall talse place as speedily as possible"

See reprints in 47 Naval WAR Colrege, Int' LAw Docusseatss 33, 16 (1952).

39. The Russians, for instance, might claim even seven years after the end of hostilities that they are not obligated under international law to return Japanese and German prisoners of war still under their control because they have not concluded treaties of peace with Germany and Japan.

40. The Peace Treaty with Japan was concluded at San Francisco, Sept. 8, 1951, si: years after her surrender. U.S. Depaktasent of State, Treaty of Pence wirh J.upa: (1952). Russia, Czechoslovalia, and Poland were present at the San Francisco Conference, but did not sign the Treaty. Id. at Introductory Remarks. "The Convention with the Federal Republic of Germany," the so-called Bonn Contractual Agrcements, to which Russia is not a party, is not a peace treaty. See Serr. Exis. Fep. No. 16, 82d Cong., 2d Sess. 10 (1952).

"The method of putting an end to hostilities by way of 'unconditional surrender' instead of the customary armistice agreements was adopted at the end of the Sccond World War. ..." 2 Oppeneres, op. cit. supra note 15, at 552.

41. See text at page 394 supra.

42. See, e.g., the statement of the French Representative to the 1949 Diplomatic Conference, MI. Lamarle. II-B Final Record of the Diplonsatic Conifeneisez of Geisema 314 (1950): 
War II repatriation experience was thoroughly examined. ${ }^{43}$ This experience provided the frame of reference for the thoughts and reactions of the Government Experts as well as the Delegates to the 1949 Geneva Conference. Certain captors forcibly retained prisoners long after hostilities ended, despite specific agreements to the contrary. ${ }^{44}$ This practice generally has been condemned as a flagrant violation of international law. ${ }^{45}$ Most prisoners of war were

43. The movement to revise the 1929 Geneva Convention began in July, 1945, when "the United States Provost Marshal General of the European Theater of Operations sug" gested to the President of the International Committee of the Red Cross that a meeting of experts on prisoner of war affairs of the various belligerent nations be callet. . . . About sixteen nations ... sent their experts to a parley at Geneva during April, 1947 [the Conference of Government Experts]. . . . The XVIIth International Conference of Red Cross invited delegations to Stockholm, Sweden, in August of 1948, to attempt at draft revision of the Convention of 1929. About sixty nations attended and two weeks of most fruitful labors utilizing the reports of the 1947 conference of experts brought forth a draft revision [of the 1929 Convention] which became the working text of the [1949] Diplomatic Conference. ..." Dillon, The Genesis of the 1949 Convention Relative to the Treatment of Prisoners of War, 5 MIaMi L.Q. 40, 43-4 (1950). See also Pictet, The New Geneva Conventions for the Protection of War Victims, 45 Ax. J. INT'L $L$. 462 (1951).

44. Russia still retains many hundreds of thousands of foreign nationals taken captive during World War II. In 1950 it was estimated that at least 1,500,000 Germans and Japanese prisoners of war were "missing" in Russia. See NoRTh ATLANTIC InForMution Service, Atrantic Series, Informiation Bulletin No. 60 (1952). Many of these, of course, can be presumed to be dead. It has been alleged further that some missing Japanese were last known to be in territory under Chinese communist control. N.Y. Times, Aug. 28,1952 , p. 6 , col. 5 .

Soviet retention of prisoners of war is not only contrary to the spirit of the 1929 Geneva Convention, but to specific agreements made with her wartime Allies as well. For a reprint of the Agrebsent of Foreign Ministers at Moscow, Regarding Repatrua* tion of Geraran War Prisoners, of April 23, 1947, see 23 Dep'r State Bull. 431 (1950); for the Porsdan Declaration Defining Terras for Japanese Surrender, July 26, 1945, \& 9, and the Agrement Between the U.S.S.R. AND the Supheme Commander for the Aluied Powers in Japan, Dec. 19, 1946, see ibid. See also Deverall, Japan's Soviet Held Prisoners of War (1951); Fehlung, One Great Prison (1951).

45. At the request of Australia, the United Kingdom, and the United States, the question of the "failure of the Union of Soviet Socialist Republics to repatriate or otherwise account for prisoners of war detained in Soviet territory" was placed on the agenda of the fifth session of the General Assembly of the United Nations. The complaint was considered for many months by two committees of the General Assembly. YEArsook of THE United Nations-1950, p. 564 (1951). A resolution (427(V)) of December 14, 1950, adopted at the 325th plenary meeting of the General Assembly, set up an ad hoc committee to investigate the matter of "missing" prisoners of war. Id. at 568. It was asserted in this resolution "that all prisoners having originally come within the control of the Allied Powers as a consequence of the Second World War should either have beet1 repatriated long since or have been otherwise accounted for." U.N. Doc. A/1749, p. 1 (1950). Russia has consistently refused to cooperate with this committee, which was established "with a view to settling the question of the prisoners of war in a purely humanitarian spirit," although the committec has attempted to be as conciliatory as possible in order to reach a solution "on terms acceptable to all the governments concerned." Note, 5 International Organization 728 (1951). 
repatriated without being offered a choice; nor did they claim that they should be given one. The Red Cross also reported to the Delegates that
"[i]t happened fairly often [after World War II] that POIV were repatriated against their will. This led to numerous suicides, as POIV were sometimes afraid, with or without valid reason, to return home."46

These forced repatriations were discussed by the Delegates, but not condemned. For those prisoners of war who were returned home against their will were repatriated to territory under allied control where no threat to their basic human rights existed. 17 Some states, however, did base repatriation on prisoners' choice. After World Wrar II, England and France needed manpower and gave enemy prisoners of war under their control the alternative of returning home or remaining. ${ }^{48}$ And the Russians announced that certain enemy soldiers could choose whether they wished to remain in Russia,

46. Geneva Convention of $J_{n l y} 27,1929$, relatize to the Trcatment of Prisencrs of War in 2 Connission of Governarent Experts, Premrnwary Docune::ts Sun:utred by the International CoNantrtee of the Red Ceoss 187 (1947).

"Many prisoners of war of Italian and German nationality desired to remain in this country [the United States] rather than be repatriated. ... The policy was adorted early in the prisoner-of-war program that every prisoner of war must be repatriated and that none could remain here as residents or citizens irrespective of their desire or supporting reasons. No exception was made to this rule." Tollefson, Enemy Prisoners of I"ar, 32 IOWA L. REv. 51, 75 (1946).

The only recorded case in the United States of a prisoner insisting that he should not be repatriated is that of Mario D'Elia, an Italian prisoner of war. The Department of the Judge Advocate General of the Army recognized that Art. 75 of the 1929 Geneva Convention did not require that $D^{\prime} E$ lia be repatriated against his wishes, and that whether or not he should be allowed to remain in the United States was a question of policy. Mearosanduns for the Judge Auvocate General, Subject: Repataistion or Italin: Prisoners of War After Cessation of Hostmlities (Jan. 15, 1945). In re Territo, 156 F.2d 142 (9th Cir. 1946), is concerned only with the question of the proper critsris for determining whether a captive is or is not a prisoner of war. An "obligation" of detaining powers to repatriate or release was mentioned only as dictum in the opinion of the District and Circuit Courts. Id. at $144,145$.

47. The Russian ex-soldiers who were forcibly returned to Russia in the Fall of 1945 from the U.S. Zone of Germany were not sent back under Art. 75 of the 1929 Genew Convention. Since they had been liberated they no longer had the status of prisoners of war. They were turned over to the Russian army under the AGReniesir Relatris 30 Prisoners of War and Civilians Liberated ay Forces Operatnig Under Uinted States of Amierica Comarand (concluded at Yalta, Feb. 11, 1945) (usually cited as the DeaneGryzlov Agreement) to facilitate speedy repatriation. See 14 Dep'r STATz BuLl. 443-5 (1946).

48. In 1948, 24,000 English-held German prisoners of war chose to remain in England rather than return home. Stadulis, The Resettlement of Displaced Persons in the United Kingdom, 5 Populatron Studres 207, 213 (1952). Regarding the choice given French-held German prisoners of war see, e.g., Byanes, Spenkrric Fraisily 169-9 (1947); 18 Dep't State Butr. 221 (1948). 
return home, or go elsewhere. ${ }^{49}$ As an inducement to surrender, the Soviet commander at Stalingrad guaranteed officers and soldiers the choice of $\mathrm{re}$ turning after the war to Germany "or to any other country where the prisoner of war should desire to go."50 At Budapest the Russians made a similar proposal. 51

Although aware of this variety of practices, the Government Experts preferred to frame a general repatriation article, rather than provide in detail for specific problems that might arise. ${ }^{52}$ The Rapporteur invited discussion on whether the Conference wished to prohibit a detaining power from repatriating unwilling prisoners, but none was forthcoming; no proposals were made. ${ }^{53}$ The Experts feared that detaining powers, under the guise of compliance with a provision making exceptions to repatriation, might prevent captives from returning home. General Bryan, the American delegate, warned that "if we allow escape clauses in this article, we risk reducing the [repatriation] principle to nothing." 54 The fact that Russia retained prisoners captured during World War II, in violation of special agreements, ${ }^{\text {} 55}$ may have provided a basis for this fear.

At the Diplomatic Conference held at Geneva in 1949, discussion focused on the relation between repatriation and asylum. ${ }^{56}$ The consensus at the Conference was that detaining powers had granted asylum in the past and would do so in the future. What particularly concerned the Delegates was whether or not detaining powers should be obligated to extend permanent asylum to prisoners of war unwilling to be repatriated. ${ }^{67}$ The Delegates concurred ${ }^{58}$ in the Government Experts' earlier refusal to impose this obli-

49. International Free Trade Union News, July, 1952, p. 1, col. 2; Izvestia, Jan. 17, 1943, p. 1, (offer at Stalingrad); Krasnia Zvezva, Jan. 1, 1945 (offer at Budapest).

50. International Free Trade Union News, July, 1952, p. 1, col. 2.

51. Hungarian captives were promised a screening process to determine whether they wished to be repatriated or not. Ibid.

52. CONFEREnce d'Experts GOUVERNMENTAUX POUR L'EtUde des Conventions Protegeant les Victimes de la Gurere, Geneve, 14-26 Avril, 1947, PV, Conimission II, Vol. III, tome 3, p. 340 (1947).

53. Ibid.

54. Ibid.

55. See note 44 supra.

56. II-B Final RECORD, op. cit. supra nate 42, at 313, 314. During these discussions what is now Article 118 was then Article 108 of the DrAfT Revised or NEw CONvENrions for the PRotection of WAR VICTIMS (1948). The discussion on asylum was produced by the provision of the last paragraph of Article 109 (then Article 100 of the so-called "Stockholm Draft") which provides: "No sick or injured prisoner of war who is eligible for repatriation under the first paragraph of this Article, may be repatriated against his will during hostilities." This article requires only temporary asylum, i.e., asylum during hostilities.

57. II-B Final RECORd, op. cit. supra note 42, at 312-14. infra.

58. For the relevant opinion expressed at the Diplomatic Conference sce note 62 
gation. ${ }^{58}$ A major reason for the Delegates' refusal is found in the following summary of the Canadian representative's statement:

"He urged that no Detaining Power should be compelled to keep in its territory prisoners of war who did not wish to return home. It might even be dangerous particularly for small States, to retain too large a number of prisoners in their territory. He was certain that if a prisoner produced valid reasons for refusing repatriation (for instance, danger of death in the event of returning to his own country), no camp commandant would repatriate him against his will, at least in Canada." 60

The Delegates also rejected the further suggestion that the repatriation articles expressly should grant detaining powers an option to accede or not to prisoners' requests to avoid repatriation. 01 Apart from previously mentioned objections to "escape clauses" by the Government Experts, the Delegates felt such an express option might create the unjustified expactation in prisoners that they could claim asylum as a right. But British and French representatives at the Diplomatic Conference felt strongly that the Convention should not alter the established doctrine and practices of asylum. Although, at the time, the wording of another article was under discussion, the statements of these representatives were apparently applicable to all repatriation situations. The traditional discretion of nation states to grant or withhold asylum, they declared, was not to be impaired. ${ }^{62}$ Available evidence does not indicate that these declarations were contradicted.

One episode in the legislative history of Article 118 deserves special mention because of the emphasis Mr. Vyshinsky has placed upon it ${ }^{63}$ and because it represents the only occasion on which a non-repatriation proposal came to a vote. The rejection by the Diplomatic Conference of the Austrian proposal that "prisoners of war must have the option of not returning to their country if they so desire"gs has been cited as conclusive proof that Article

59. CONFEREATCE D'EXPERTs, op. cit. supra note 52, at 340-2.

60. II-A FINAL RECORD, op. cit. supra note 42, at 291 (statement in connection with Art. 109; emphasis added).

61. See II-B id. at 312-14. See also discussion, text at page 402 sugra.

62. See II-B FiNAL RecoRd, op. cit. supro note 42, at 312-14. Concerning Art. 109, the U.K. representative, Mr. Gardiner, stated : "I suggest that a country should be allowed to decide for itself whether it vill give refuge and asylum to a foreigner who has come to that country not by a voluntary act of his own; for instance, when a Detaining Power is satisfied that he has good grounds for staying, but there should not be an obligation on the Detaining Power to keep a prisoner of war. . . "Id. at 313. MI. Lamarle of France supported Mr. Gardiner: "Moreover, as the United Kingdom Delegate pointed out, no question of any kind of right of sanctuary arises. . . . It is natural, however, or at least it seems natural to me ... that the Detaining Power should reserve its own diccretion. This would of course not prevent it from taling account of any circumstances which scemed to merit consideration." Id. at 314.

63. See Vyshinshy's statement, U.S. Deles., op. cit. supra note 18 , at 88 .

64. II-A FinAl Recosd, op. cit. sispra note 42, at 402 . 
118 provides no exceptions for prisoners who do not wish to be repatriated. The proposal read:

"Subject to the provisions of the following paragraph, prisoners of war shall be repatriated to the country whose nationals they are at the time of their repatriation.

"Prisoners of war, however, shall be entitled to apply for their transfer to any other country which is ready to accept them."

This amendment was rejected by a "large majority."'67 Both the Russian and the American delegates voted against it. ${ }^{68}$

The Delegates seem to have defeated the amendment decisively for the same reasons they had not included in Article 118 either an obligation or an express option to grant asylum. First, General Sklyarov presented the official Russian position when he expressed his fear "that a prisoner of war might not be able to express himself with complete freedom when he was in captivity." He further claimed that such a "provision might give rise to the exercise of undue pressure on the part of the Detaining Power." 69 Russian desire to avoid escape clauses may also have reflected her fear that in the event of a future conflict many captured Russian soldiers would not return home if given a choice. $^{70}$ The American delegation was concerned lest such a clause might tempt detaining powers in a future war to force American captives to state that they do not wish repatriation. ${ }^{71}$ Thus one reason for rejection was the desire not to give an escape clause the sanction of treaty words. But a second, and more compelling reason for rejection seems to stem from the actual language of the Austrian proposal. The clear implication of the amendment was that it imposed on the captor country an obligation to grant at least temporary asylum, and that it entitled the prisoners to demand transfer to a third country. At an earlier stage of the Conference, the Delegates had found such an obligation objectionable. And Mr. Gardiner, the British delegate,

65. See, c.g., Vyshinky's statement, U.S. DELEG., op cit. supra note 18 , at 88 .

66. II-A Final ReCoRd, op. cit. supra note 42, at 324.

67. Id. at 462 .

68. Ibid.

69. Ibid.

70. The resistance to repatriation by many Russian nationals after World War II shows these fears were well founded. "There were large numbers [in the United States Zone of Germany] who did not wish to be repatriated because of their political beliefs, including the Baltic people and the western Ukrainians, whose states had been absorbed by the Soviet Union." Clay, Decision in Germany 231-2 (1950). See also the Editorial in 62 The Christran Century 1373 (1945); Penrose, Negotialing on Refuges and Displaced Persons, 1946 in Dennemt \& Johnson, Negotiating witu tue Russians 139, 140 (1951) ; UNRRA, The Central Comsittee of the Council, Documents of the Special Subcomaittee on Resolution 71, Feb. 12, 1946: Report on the AdministraTION'S Operations under Resolution 71, Doc. CC/SS(46)4, p. 3 (1946).

71. The same attitude was displayed by the American delegates at the Conference of Government Experts in 1947. See text at page 402 supra. 
felt the Austrian proposal further obliged captors to accede to priconers' demands for transfer to a third country.72 Because these were the reasons for rejection, defeat of the Austrian proposal provides no support for the position that Article 118 requires repatriation of each and every prisoner.

Thus nothing exists in the text of the 1949 Geneva Convention or in the record of the conferences preceding it to indicate that states were meant to be prohibited from granting asylum to prisoners of war. And in the light of the variety of World War II repatriation practices, it is clear that the Delegates assumed that offering asylum was compatible with the new repatriation article and general international law.

Article 118 recognizes that the paramount desire of prisoners of war is "to be returned as quickly as possible to the sphere of their national activities."73 Since for most prisoners failure to be returned would be a major deprivation, repatriation is protected as a "right." And Articles $\sigma$ and 7 protect "rights" established by the Convention. Article 6 it forbids governments concerned from bargaining away "rights" of prisoners; Article 7 restrains war prisoners themselves from doing so. If, however, a prisoner opposes repatriation and it is deemed that returning him will endanger his life, liberty or dignity, to say that a man loses a "right" by not being forced home under such circumstances is strange doctrine indeed. It is proper for a home state to insist that "rights" of prisoners guaranteed under the Convention be honored. If repatriation, however, would amount to a denial of human rights, a home state's insistence that its nationals be returned, based on a claim that it is protecting a right, should not be honored. For forcible repatriation under these circumstances would represent a perversion of the purposes of the entire Convention.

\section{Legislative History: International Law Doctrink and Practice}

Article 118 was drafted to set forth clearly and unequivocally a right to be repatriated. Articles 6 and 7 were included to protect that right and others. But the records of the proceedings further show the desire of the Convention

72. II-A Final ReCoRd, op. cit. supra note 42 , at 324.

73. Statement of the Belgian representative at the 1949 Diplomatic Conference. II-A FinAL Record, op. cit. supra note 42, at 295-6.

74. Geneva Contention Rezative to the Treatusent of Prisoners of Was of August 12, 1949, Art. 6 (1949) reads: "In addition to the agreements expressly provided for in Articles 10, 23, 28, 33, 60,65, 66, 67, 72, 73, 75, 109, 110, 118, 119, 122 and 132, the High Contracting Parties may conclude other special agreements for all matters cuncerning which they may deem it suitable to malie separate provision. No special agreement shall adversely affect the situation of prisoners of war, as defined by the present Convention, nor restrict the rights which it confers upon them.

"Prisoners of war shall continue to have the benefit of such agreements as long as the Convention is applicable to them, except where express provisions to the contrary are contained in the aforesaid or in subsequent agreements, or where mure iavuratle mis. sures have been taken with regard to them by one or other of the Parties to the conflict." 
drafters not to discard, but rather to implement, relevant general doctrines and practices of international law, 75 in existence long before 1949.

The most comprehensive statement of these principles is found in the Universal Declaration of Human Rights. ${ }^{70}$ The Declaration affirms a "faitl in fundamental human rights, in the dignity and worth of the human person" without which achievement of long-range United Nations goals, as mapped by the Charter, would be impossible. ${ }^{77}$ The United Nations interpretation of the 1949 Convention is consistent with fundamental individual rights set out in the Declaration. A right to be repatriated is a specific application of the right "to leave any country and to ... return to [it]" (Art. 13(2)) and not to "be arbitrarily deprived of ... nationality" (Art. 15(2)). Article 9 of the Declaration-"No one shall be subjected to arbitrary ... detention or exile" -buttresses the position that Article 118 prohibits captors from forcibly retaining prisoners of war. These principles as well as the words of $\Lambda$ rticle 118 provide strong support for the proposition that a prisoner's desire to be repatriated must be honored. But the right to "life, liberty and the security of person" (Art. 3), the right not to be subjected to "slavery or servitude" (Art. 4), the right not to "be subjected to torture or to cruel, inhuman or degrading treatment or punishment" (Art. 5), the right "to seek and enjoy in other countries asylum from persecution" (Art. 14, § 1)-these rights would be denied if prisoners were repatriated by force to slave labor camps or firing squads.

Principles of the Universal Declaration have been recognized in tratditional international law. States have protected human rights by granting asylum, long an international institution. ${ }^{78}$ The United States throughout her history has exercised the right to grant asylum. ${ }^{70}$ Moreover, she has consistently

75. See text at pages 402-3 supra.

76. For two views on the importance and legal authority of the Universal Declaration of Human Rights, see U.N., THE Irrpact of the Universal DeCLARATION OF HUinaN Rights, U.N. Pub. ST/SOA/5, pp. 3-8 (1952), and LaUterpacht, InterNational LaW AND HIUMAN RIGHTS 394-428 (1950).

77. One of the aims of the United Nations is to act so as "to reaffirm faith in futcdimental human rights, in the dignity and worth of the human person, in the equal rights of men and women and of nations large and small." U.N. ChrnRTEk Preamble. One of its purposes is to promote and encourage "respect for human rights and for fundamental freedoms for all. ..." Id. at Art. 1.

78. See, e.g., Fenwick, International Law 473-4 (3d ed. 1948); 2 Hackwontu, Digest of Internationas Law $\$ 191-6$ (1941); 2 Hyde, International LAw 1014 (2d ed. 1945); 1 Oppenteis, International LAw \$ 316 (7th cd., Lauterpacht, 1948); Reale, Le Droit d'Asile, 63 Hague Recueil des Cours 470 (1938); Colombian-Peruvian Asylum Case, I.C.J. Reports 266, 274 (1950).

The asylum referred to in the text is not the controversial "diplomatic asylum."

79. ". . . [I]t is the traditional policy of the Government of the United States to grant refuge in its territory to persons whose lives are believed to be in jcopardy as a result of their political activities in a foreign country." Quoted in 3 HAckwostu, op. cit. supra note 78, at 734. For recent instances which apply this principle, see N.Y. 'l'ints, Aug. 20, 1952, p. 3, col. 7; Sept. 19, 1952, p. 3, col. 5 . 
refused to extradite aliens likely to face persecution. ${ }^{80}$ Constitutions of the Soviet Union and many of her satellites proclaim that "those persecuted for defending the interests of the working people, or for their scientific activities, or for their struggle for national liberation" have a right of asylum within these countries. ${ }^{81}$ Constitutions of certain western nations extend a right of asylum to those persecuted for "political" reasons. 82 Most states, however, do not extend asylum as a right. ${ }^{83}$ These disparate views conform to general international law, which holds that on the question of refusing to admit or expel aliens the state is sovereign. ${ }^{84} \mathrm{By}$ involing asylum a captor can thus justify its refusal to repatriate prisoners of war whose rights might be violated if they are forced to return. Mr. Vyshinshy argues that prisoners have no right to seek and enjoy a grant of territorial asylum, because of their special status as soldiers of their nation-states.

80. "In almost all extradition treaties to which the Unitcd States has bren a party there is a provision expressly declaring that persons charged with the commission of political offenses shall not be surrendered." $2 \mathrm{HynE}$, op. cit. supra note 78, at 1020 . Sse also the statement of Secretary of State Hamilton Fish: "A large proportion of those why sought refuge on our shores prior to the formation of this Government, saught this country for the enjoyment of freedom of opinion on political and religious subjests, and their descendants have not forgotten the value of an asylum nor the obligation of a state to shelter and protect political refugees. Neither the extradition clause in the treaty of 1794 nor in that of 1842 contains any reference to immunity for political offenses, or to the protection of asylum for political or religious refugees. The public sentiment of bath countries made it unnecessary. Between the United States and Great Britain, it was not supposed, on either side, that guarantees were required of each other against a thing inherently impossible. ..." Departarent of State, Foreign Rerations or tae Uimited STATES-1876, p. 237 (1876).

S1. U.S.S.R. Const. Art. 129 (1936) (reprinted in Yenrfoor of Husch: RIGBTS For 1946, p. 316 (1947)). See comments in Vysumskx, Tur, Law uF the Sunet Srate 633-6 (Babb's transl. 1948). For a typical "People's Republic" following the language of the U.S.S.R. Const., see ALBAnta Const. Art. 36 (1946) (reprinted in Yearcoors of HUMAN Rights FoR 1946, p. 5 (1947)).

82. See, e.g., France Const. Preamble (1946) (reprinted in Yearcoors or Hunazi RIGHTS FOR 1946, p. 105 (1947)).

Constitutions of certain Latin American states offer asylum as a right to Erscons persecuted "for political reasons." E.g., Constirctios of Clas, Jizr, 1940, Art. 31 (reprinted in YeAREOOK of HussaN RigHTS FOR 1946, p. 75 (1947)).

83. Most states have not admitted a right of individuals to demand and to receive asylum in their territory. 1 Opfeingers, of. cit. supra nute 78, at 618 ; Morgenstem, The Right of Asylzm, 26 ERIT. Y.E. INT'. L. 327 (1949).

For the attitude of U.S. courts, see, e.g.: "But the right is that of the State voluntarily to offer asylum, not that of the fugitive to insist on it." Chandler v. United States, 171 F.2d 921, 935 (1st Cir. 1949).

84. See, e.g., 1 OpPENHenr, op. cit. supra note 78, at 615-21. See also the position of the U.S. Supreme Court in United States v. Shaughnessy, $33 S$ U.S. 537 (1950); United States v. Trudell, 284 U.S. 279 (1932); Mahler v. Eby, 264 U.S. 32 (1924); Fong Yue Ting v. United States, 149 U.S. 698 (1893). 
"[T] They are bound by the oath of loyalty which they gave their fatherlands; ... they remain bound by their duty as soldiers to their fatherlands, their armies." 85

No authority is offered for this innovation, and there is no justification for discriminating against soldiers in such a manner. For this thinking contradicts a fundamental premise of all human rights: equal treatment for all regardless of status. Furthermore, in practice, states have given protection to prisoner:s of war who have not wished repatriation. ${ }^{80}$ Most post-World War I peace treaties and repatriation agreements permitted prisoners to remain in the terri= tory of their captor. ${ }^{87}$

Even assuming arguendo that Article 118 of the 1949 Convention uncon* ditionally requires detaining powers to repatriate all captives, ${ }^{88}$ the traditional doctrine of "humanitarian intervention"80 lends support to non-compliance

85. From Mr. Vyshinsky's statement at the 529th Meeting of Committee I of the General Assembly, Nov. 24, 1952. U.S. DenEG. Doc. U.S./A/C.1/2543, p. 5 (1952).

86. See FloRY, PrISONERS oF WAR $141-7$ (1942) and references therein cited; Camen-Salvador, Les Prisonniers de Guerre 304-5 (1929); and the report of the International Committee of the Red Cross to the Conference of Government Experts, see note 46 supra.

87. Most peace treaties and agreements relating to the repatriation of prisoners of war concluded after World War I contained provisions permitting prisoners to remain in the territory of their captors or go elsewhere. Most treaties and agreements concluded by Soviet Russia made such provisions. These treaties and agreements were cited by Secretary of State Acheson, in his statement on Korea made to Committee I of the General Assembly of the United Nations, Oct. 24, 1952. The peace treaties which the Allied and associated powers concluded with Germany, Austria and Hungary respected the wishes of prisoners of war who did not wish to be repatriated. Article 220 of the Treaty of Versailles provided that: "Prisoners of war or other German nationals who do not desire to be repatriated may be excluded from repatriation; but the Allied and Associated Governments reserve to themselves the right either to repatriate them or to take them to a neutral country or to allow them to reside in their own territories." 3 Malioy, Treattes, Conventions, International Acts, Protocols and Agreinuents Between the United States and Otmer Powers 3329, 3416 (1923). The same clauso was included in Article 166 of the Peace Treaty of St. Germain en Laye with Austria, id. at 3149, 3200; and in Article 150 of the Peace Treaty of Trianon, id. at 3539, 3586. Similar provisions were contained in the German-Latvian Agreement Concerning the Exchange of their Respective Military and Civilian Prisoners, concluded April 20, 1920, 2 League of Nations Treaty Series 74 (1920); the German-Finnish Peace Treaty, signed March 7, 1918, 10 Martens, Recueil 3D Ser. 835, 841 (1920); the Peace Treaty between Finland and Austria-Hungary, signed May 29, 1918, Art. 7, 12 MAkrens, RecueIL 3D SER. 17, 24 (1924); and the German-Polish Treaty Concerning the Liberation of Prisoners, Interned and Hostages, signed Oct. 1, 1919, Supplementary Treaty and Exchange of Notes, 16 MARTENS, RECUEIL 3d SER. 330-6 (1927).

88. This essentially is the communist position. See text at page 391 supra.

89. Although in principle a nation-state can do with its nationals what it wishes, the doctrine and practices of "humanitarian intervention" indicate that there are limits to that discretion. When a state treats its nationals in such a way as to shock the conscience of mankind, intervention in the interest of humanity may be legally permissible 
with such a rule where prisoners' human rights might be violated. The United Nations Charter has not abolished "humanitarian intervention"; the Charter merely prohibits interference "in matters which essentially are within the domestic jurisdiction of any state." If there is widespread denial of basic human rights, a state cannot invoke domestic jurisdiction despite the fact that the violations occur within the state's own territory and are imposed on its nationals. By authorizing a three-man commission to investigate race policies of Prime Minister Malan's South African government, the United Nations recognized that a state's attack on the basic human rights of its citizens threatens peace and therefore is a matter of international, not domestic concern. ${ }^{91}$ Refusal to repatriate prisoners of war in the name of human rights resembles humanitarian intervention, but the two are not identical since this refusal does not involve a violation of territorial sovereignty. Under our present assumption, refusal to repatriate violates a treaty provision-Article 118. Yet treaties or rules of customary international law become inspplicable when the needs of the world community require non-compliance. 02 Since even the sacrosanct principle of territorial sovereignty can be overridden to protect human rights, a specific treaty provision cannot thwart achievement of humanitarian goals, especially when the treaty itself was conceived solely to promote these objectives.

even though a violation of the sovereignty of another state would occur as a result. In the past, particular states have acted in accordance with "humanitarian intervention" when their sense of justice was outraged, not when rights established by international

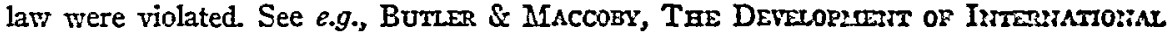
LAW 69-73 (1928) ; FENwICK, op. cit. sispra note 78, at 242; LAUTERPACET, of. cil. sispro note 76, at 120-2; 1 OPPENHEIM, op. cit. supra note 7\$, at 279-\$0; Waso: \& Tucrses, INTERNattowal LAw 95-6 (9th ed. 1935); Stowell, Hunanitarian Interiention, 33 A2s. J. INT'L L. 733 (1939).

90. "Nothing contained in the present Charter shall authorize the United Nations to intervene in matters which are essentially within the domestic jurisdiction of any state or shall require the Members to submit such matters to settlement under the present Charter...." U.N. Cenarter Art. 2, \$7. For detailed discussion of this section, see Gounfich \& Hastero, Chabter of the Uniteo Nations 110-121 (2d ed. 1949); Kelsen, The Law of THE United Nations c. 19, $\$ 1$ (1950). See also MacChesney, Intemational Protection of Human Rights in the United Nations, 47 N.U.L. REv. 198, 203-5 (1952).

91. On November 20, 1952, the General Assembly's Special Political Committee roted 35-2 to have a three-man commission "study the race situation" in South Afrien, and rejected, 45-6, South Africa's contention that the United Nations was barred from investigating this problem as a matter "essentially within the domestic jurisdiction of ... [a] state." N.Y. Times, Nov. 21, 1952, p. 1, col. 1; p. 4, col. 4.

"The General Assembly may call the attention of the Security Council to situations which are likely to endanger international peace and security." U.N. Crasrom Art. 11, \$3. "The Security Council shall determine the existence of any threat to the pesce, breach of the peace, or act of aggression and shall make recommendations, or decide what measures shall be taken ... to maintain or restore international peace and security." Id. at Art. 39.

92. 1 OpPENHERs, op. cit. supra note 78 , at 336-7. 
The literalist view that repatriation of all prisoners is mandatory disregards the purposes and history of the 1949 Geneva Convention and the need to refer to conditions prevailing at the time interpretation is made. But does the proper method of treaty interpretation obligate a state to grant asylum, or does it make refusal to repatriate merely a matter of discretion? Though those who framed the Convention followed the traditional doctrine of asylum by rejecting the suggestion that asylum should be obligatory, what they opposed was a general obligation-asylum for all prisoners under all circumstances. In the light of the mandatory provision of the Convention that "prisoners of war must at all times be humanely treated,"93 an obligation to grant asylum does exist when repatriation would result in deprivation of human rights and where the prisoner has supplied convincing evidence that in his case there is no justification for the Convention's assumption that the parnmount desire of a prisoner is to go home. Thus detaining powers must not repatriate prisoners of war if (a) it is reasonable to conclude that they would be deprived of fundamental human rights upon return; and (b) if the prisoner himself opposes repatriation so strongly that it could be effected only by using force.

\section{Applying the 1949 Geneva Convention}

After one accepts the correct interpretation of the repatriation provisions of the 1949 Geneva Convention, as the U.N. has done, the problem of application remains. The United Nations, or any future decision-maker must answer, at least by implication, these questions: What standards should be used to judge whether treatment of repatriated prisoners by the home state represents a denial of human rights? In a given situation does available evidence give reason to believe that upon repatriation prisoners would receive treatment constituting such a denial? And finally, does a prisoner of war oppose repatriation so strongly that he can be sent home only by using force?

\section{Establishing Standards}

All members of the United Nations accept certain human rights. They have agreed to the general formulae contained in the Universal Declaration of Human Rights, such as the provision that no one shall be subjected to "slavery or servitude" or "inhuman or degrading treatment or punishment." Since the communist and non-communist worlds exhibit fundamental disagreement as to what kinds of state practices must be characterized as "slavery" or "inhuman treatment," it is not now possible to articulate shared a priori standards. An illustration of this impasse is found in the failure of the Commission on Human Rights of the United Nations to draw up generally

93. Geneva Convention Relattve to the Treatment of Prisoners of War, August 12, 1949, Art. 13 (1949).

94. See text at page 406 supra. 
acceptable Covenants of Human Rights. ${ }^{35}$ When disagreement exists, however, specific meaning can still be given to general formulae by a series of authoritative decisions or shared practices. For example, general concepts of the 14th Amendment have been given specific content with respect to civil rights only after decades of judicial construction. Similarly, specific standards for general formulae of human rights may one day emerge from international, and particularly United Nations, practices and decisions. But existing inchoate standards could not serve as a reliable guide to the United Nations at the time it applied the 1949 Convention to Forea. The General Assembly avoided setting forth specific standards by which the world could judge whether the treatment accorded repatriated prisoners would represent a denial of human rights. The Resolution of December 3, 1952, presented as a basis for settlement of the prisoner problem, held only that "force shall not be used against prisoners of war to prevent or effect their return to their homelands and no violence to their dignity or self-respect shall be permitted in any manner or for any purpose whatsoever." But since, by itself, employment of force to effect repatriation has never been considered a violation of human rights, the position taken by the United Nations Command and the General Assembly must have been based on a tacit assumption that prisoners forced to return would be exposed to deprivations. This assumption was madle articulate only by leaders of the United States and Britain, who stressed that human rights are violated if repatriated prisoners are committed to forced labor camps or executed arbitrarily. ${ }^{97}$ Although Vestern values, not general international agreement, underlie the United Nations repatriation proposals, to have spelled out even these standards in the December Resolution would have filled a real need in international law.

\section{Finding the Facts}

Application of the 1949 Geneva Convention requires a factual determination of the treatment which awaits repatriated prisoners of war. Decisions on repatriation should be made with express reference to facts found through

95. At the eighth session of the Commission on Human Rights two draft covenants, one on "Civil and Political Rights," and the other on "Economic, Social and Cultural Rights," were prepared. As yet they have nut been accepted. U.N. Coxssussion o: Huaran Rights, Report of the Eighte Sessiun (14 April-14 June 1952); ECOSOC Offictal Records : FouRteentry Session, SUtP. No. 4 (1952); and 13 U.N. BULL 248-57 (1952).

96. N.Y. Times, Dec. 2, 1952, p. 3, col. 1; Dec. 4, 1952, p. 3, col. 1. The U.N. Resolution, as Mr. Vyshinsky has pointed out, is not clear as to whether the use of force or the return itself would be a violation of human rights.

97. In a speech at Guildhall, London on November 10,1952, Prime Minister Churchill declared: "It would be dishonour to send thousands of helpless prisoners of war bacls by force to be massacred by a Chinese Communist Government which boasts that it has actually rid itself of two millions of its own people." The Times, Nov. 11, 1952, p. 6, col. 6. See also President Truman's statement, text at Irage 392, sufro. 
adequate fact finding procedures. In the present controversy United Nations pronouncements and General Assembly debates have referred to no specific information on relevant Chinese and North Korean practices. What has been said is contained in the general statements of Western leaders. But we must assume that those responsible for the United Nations stand on repatriation concluded from a study of available information that prisoners forcibly returned to North Korea and China most likely would be sent to forced labor camps or arbitrarily executed. However, reference to these facts by the United Nations Command or the General Assembly would have made communist acceptance of U.N. proposals impossible from the outset. Although the information relied on by the United Nations may have been gathered by objective observers, under ideal conditions fact finding should not be left to any nation or organization with a direct stake in the outcome of the investigation. But Chinese and North Korean communists have allowed no organization, including the traditionally neutral Red Cross, to investigate even their prisoner-of-war camps. ${ }^{98}$ In view of this opposition, it would be naive to expect the communist governments to acquiesce in an investigation of treatment accorded their own nationals. Furthermore, attempts to conclide speedy armistice surely would have been frustrated by United Nations insistence on a formal fact finding process as a prerequisite to the settlement of the repatriation issue.

\section{Ascertaining Prisoners Resistance to Repatriation}

If the facts show that repatriation endangers prisoners' rights, there remains the task of ascertaining the degree of prisoner resistance to repatriation. The actual use of force is the only direct way of finding out if force is necessary. But this technique would be repugnant to accepted concepts of human dignity. There are other methods, however, for making the necessary prediction. Perhaps responses elicited during interrogation provide the most reliable means of prediction. Whatever specific method is used, the aim should be to obtain a reaction not evoked by intimidation or misleading propaganda.

The United Nations attempted to obtain such a response in April, 1952, when it interrogated most Chinese and Korean captives. Some cotuld not be questioned, because opposition to interrogation was too strong in communist-dominated POW compounds.0 Written notices appeared in the camps, and announcements were made over public address systems that all persons were to be interrogated by impartial United Nations Command personnel to decide who would want to be repatriated and who had "compelling reasons" for refusing repatriation. ${ }^{100}$ These announcements emphasized the

98. Departacent of State, The Problem of Peace in Korea-An Oral Report by Secretary of State Dean Acheson, October 24, 1952, pp. $29-30$ (1952).

99. Korea : A SuMMcary, op. cit. supra note 1 , at 10.

100. Id. at 10, 19 (Annex XIII). 
importance of the decision about to be made by the prisoner and its possible adverse effects on his family at home. Full publicity was given to communist assurances of amnesty to all prisoners regardless of their conduct while captives of the United Nations. ${ }^{101}$ An interviewer questioned each person separately. Koreans were interrogated by South Korean civilians under the general supervision of United States personnel, while the Chinese vere screened by Chinese speaking United States servicemen. ${ }^{102}$ On the basis of a prisoner's answers to specific questions, ${ }^{103}$ the United Nations predicted whether or not force would be necessary to effect his return. Unless answers indicated the person would commit suicide, escape, fight to the death, or talie other desperate measures to avoid repatriation, the individual was placed on the list of those who were to be sent home. ${ }^{10-1}$ It is possible that these tests of a prisoner's opposition were even stricter than might be necessary to show: that force would be needed to effect repatriation.

This screening process was attacked in the United Nations by Mr. Vyshinsky. He argued that the April screening, or any other interrogation of war captives, even under the most ideal conditions, could not be free of coercion.

"[T] hey [the supporters of the United Nations position] completely ignore the simple and elementary idea that under conditions of war imprisonment there is not and cannot be the most minimum conditions for the free expression of the will of any war prisoner."105

But those who drafted the 1949 Geneva Convention-Russians among them -assumed that a free expression of will under conditions of war imprisonment is possible, for Article 109 of the Convention provides that a sicls or wounded prisoner eligible to be sent home is not to be "repatriated against his will during hostilities." Perhaps the United Nations might have avoided some attacks on the screening process if it had delegated the interrogation to a

101. Id. at 10 .

102. Ibid. The entire interrogation lasted ninety seconds. Barrett \& Barrett, Why Our Red Prisoners Refuse to Go Honte, 7 The Reporter, Aug. 5, 1952, p. 22.

103. Questions put to Chinese prisoners during the April screening were as follows:

“1. Will you voluntarily be repatriated to North Korea or China?

"2. Would you forcibly resist repatriation?

"3. Have you carefully considered the impact of such action on your family?

“4. Do you realise that you may remain here at Koje-do long after those electing repatriation have been returned home?

"5. Do you realise that the UNC cannot promise that you will be sent to any certain place?

"6. Are you still determined that you would violently resist repatriation?

"7. What would you do if you were repatriated in spite of this decision?"

Similar questions were put to North Korean prisoners during the April screening. KOREA: A SUMSALARY, op. cit. sispra note 1, at 21.

104. N.Y. Times, Miay 29, 1952, p. 2 , col. 2.

105. Mr. Vyshinsky's statement at the 521st Meeting of Committee In Nuv. 10, 1952 U.S. DELEG. DoC. U.S./A/C.1/2540, p. 19 (1952). 
neutral nation or organization. But even the Repatriation Commission, proposed in the December Resolution of the General Assembly, might be charged with bias. For in a bi-polar world it is difficult to find an organization or state not exposed to accusations of partiality. ${ }^{108}$

Application of the correct interpretation of the 1949 Convention may pose the practical problem of what to do with large numbers of men. Detaining powers obligated to grant prisoners permanent asylum would be saddled with serious and often unjustifiable burdens, as the Delegates to the 1949 Diplomatic Conference pointed out. ${ }^{107}$ For this reason, most states have opposed the articulation of a right to asylum. ${ }^{108}$ Thus many belligerents might refuse to apply the correct interpretation of the Convention if the obligation not to repatriate were to involve a further obligation to provide a permanent home for displaced prisoners. After World War II the responsibility for the care and resettlement of displaced persons was declared to be a matter of international concern. ${ }^{100}$ Similarly, the burden of providing for non-repatriated prisoners of war should not be placed on detaining powers alone, but rather on some international organization. Shifting the responsibility in this fashion would ease the fear expressed at the 1949 Geneva Conference that a grant of asylum will impose immense burdens on captor states. Though the postWorld War II agencies for the care of refugees-UNRRA and IRO-have been disbanded, the United Nations' High Commissioner for Refugees 110 might be entrusted with the ultimate responsibility for non-repatriable prisoners of the Korean conflict or future wars. The United Nations Resolution of December 3, 1952, calls upon a post-armistice "political conference" to arrange for the disposition of unrepatriated Korean captives. If this conference cannot solve the problem within 30 days, the responsibility is to devolve upon the United Nations. ${ }^{111}$ But whatever organization is assigned this

106. Witness the current attacks being leveled at the International Red Cross. These reached their height at the July, 1952, International Red Cross Conference. As a result "the first serious pessimism regarding the future of the Red Cross had begun to preoccupy many of the delegates." N.Y. Times, July 31, 1952, p. 2, col. 5.

107. See text at page 403 supra.

108. See text at pages 403-5 supra.

109. See Ristelhueber, The International Refugee Organization, 470 InTERNATIONAt. Conciliation 167, 174-85 (1951); Raymond, The Juridical Status of Displaced Persons from Soviet and Soviet-jominated Territory 167 (unpublished thesis in Library of Congress, 1952).

110. For a discussion of his functions see YeArbooK of tHE UNITED NATIONS-1950, p. 21 (1951).

111. "At the end of ninety days, after the armistice agreement has been signed, the disposition of any prisoners of war whose return to their homelands may not have been effected in accordance with the procedure set out in these proposals or as otherwise agreed, shall be referred with recommendations for their disposition, including a target 
problem, the solution reached must provide a brighter future than the one from which the United Nations offers refuge.

\section{A New Point of Departure}

That international law should govern the Korean repatriation issue is the common ground on which the communists and the United Nations stand. Disagreement results from conflicting views of what the 1949 Geneva Convention provides for the Korean situation. Claiming that its position is "wholly consistent with" the Convention, and required by its general humanitarian principles, the United Nations holds that no prisoner will be forcibly repatriated. The communists insist that Article 118 , read in conjunction with Articles 6 and 7, embodies "the law" and requires that all captives, without exception, be repatriated. However, Article 118, in which Mr. Vyshinsky finds his "categoric formula," is directly applicable only "after cessation of hostilities." These words were used to characterize a situation where no military reason could justify the continued captivity of prisoners. The actions and attitudes of both parties, however, indicate that the situation characterized in Article 118 will not result from the conclusion of an armistice. The Russians themselves have said the cold war will continue. And concern over defensible cease-fire lines and the rate of troop rotation during the nergotiations seems to indicate both parties believe military needs will be paramount even after an armistice is concluded. Perhaps, then, through a fresh appraisal of the facts, the communists and the United Nations can agree on a repatriation formula based on another provision of the Convention. Article 109 might serve this purpose. This article is designed to encourage exchange of prisoners when the conditions referred to in Article 118 are not present. Article 109, in part, provides that during hostilities, "Parties ... may . . . conclude agreements with a view to the direct repatriation or internment in a neutral country of ... prisoners of war who have undergone a long period of captivity." This provision contains nothing which can be construed as a "categoric formula." Thus a state need not feel compelled by Convention language to insist upon the repatriation of all prisoners without exception.

In many disputes the re-examination of the factual premises on which seemingly irreconcilable positions are based has opened new arenues to honorable agreement. Yet even if the United Nations and the communists should re-examine their positions, any agreement which might result must preserve and promote the humanitarian purposes of the 1949 Geneva Convention.

date for the termination of their detention, to the political confererice to be called as provided uider Article 60 of the draft armistice agreement. If, at the end of a further thirty days, there are any prisoners of war whose return to their homelands has not been effected or provided for by the political conference the responsibility for their care and maintenance until the end of their detention shall be transferred to the United Nations." N.Y. Times, Dec. 2, 1952, p. 3, col. 6. 


\title{
THE YALE LAW JOURNAL
}

\begin{tabular}{lll} 
VoLUMe 62 & FEBRUARY, 1953 & NUMBer 3 \\
\hline
\end{tabular}

\author{
EDITORIAL BOARD \\ ERNEst Rubenstein \\ Editor-in-Chief \\ ARNOLd M. LERASAN \\ WILLIAM R. MURPHY \\ Executive Editors \\ JoHN G. SIMON \\ Article and \\ Book Review Editor
}

WILLIAM M. BRADNER ANDREw C. Hartzel., JR. STUART C. LAW StUart Robinowitz

JOHN W. Frommer, Jw. Case Editor

Charles R. Bergoffen Maurice N. Nessen Managing Editors

\section{Note and Comment Editors}

George Berlstern Theron L. Caude, Jr. Peter S. Craig Willtam A. Delano
IMMANUEA KoHN RICHARD I. M. KeltoN LEONARD M. PolasAl: JEROME S. WAGSHAL
Kiaus Dohnanyi JOHN D. FASSETT Charles E. Fraser ARTHUR B. FroMMMER ANDREw D. HEINEMAN, Bus. Mgr.

Editor in Military Service

BARRY H. GaRfINKEL, Managing Editor

MARIE MCMAHON

Business Secretary

\section{CONTRIBUTORS TO THIS ISSUE}

Grorge H. Dession. B.A. 1926, M.A. 1927, Cornell Univeristy; LL.B. 1930, Yale University. Member of the United States Supreme Court Advisory Committee on Rules of Criminal Procedure, 1940-6. Co-chairman, Yale Study Unit in Psychiatry and Law. Lines Professor of Law, Yale Law School.

Lawrence Z. Freedaran, M.D. B.S. 1941, Tufts College; M.D. 1944, Tufts Medical School. Consultant to United Nations Economic and Social Council in Criminology, 1949-50. Chairman, Yale Study. Unit in Psychiatry and Law. Cooperating Faculty Member, Yale Law School. Assistant Professor of Psychiatry, Yale University School of Medicine.

RICEard C. Donneliy. Ph.B. 1936, Washburn College; LL.B. 1938, Washburn University; J.S.D. 1949, Yale Law School. Associate Professor of Law, Yale Law School.

Frederick C. Redlich, M.D. M.D. 1935, University of Vienna Medical School. Member, New York Psychoanalytic Society. Cooperating Faculty Member, Yale Law School. Professor of Psychiatry and Chairman, Department of Psychiatry, Yalc University School of Medicine.

FElix S. Conen. A.B. 1926, City College of New York; A.M. 1927, Ph.D. 1929, Harvard University; LL.B. 1931, Columbia University. Author: HANDEOok of FEDERAt, INDIAN LAW (1941). Member, New York and District of Columbia Bars. Visiting Professor, City College of New York. Visiting Lecturer, Yale Law School.

JAN P. Chararatz. J.U.D. 1933, University of Prague; LL.M. 1952, Yale University. Formerly Professor of Law and Professor of Social Science, University of Pucto Rico; Trial Attorney and Associate Prosecutor, Office of Chief of Counsel for War Crimes; Privatdozent, University of Prague. Visiting Lecturer in Law, Yale Law School.

Harold MC. Wrr. A.B. 1949, Harvard University. Student, Yale Law School, 1949. 51 ; currently on leave of absence. Active duty, Lieutenant (j.g.), U.S.N.R. 